\title{
Wind Energy Potential Estimation in Pirgulu Region
}

\author{
Ulviyya Mammadova
}

Department of Soils Ecology and Bonitation, Institute of Soilscience and A grochemistry of ANAS, Baki, AZ1073, Azerbaijan

\begin{abstract}
Beside other innate resources Pirgulu has rich wind energy potential. Renewable energy application in the surrounding villages next to Pigulu preserve is possible after having estimated the local potential, due to the existing methods the ensurating of wind energy parameters and proceeding of these data have been realized. Average annual amount of windy, windless and total wind energy potential were determined in the region. Also the quantity of windy days possessing more than $15 \mathrm{~m} / \mathrm{sec}$ wind speed in the territory. Finally wind energy potential map was established in electron version using arc-view program.
\end{abstract}

Keywo rds Wind Potential, Renewable, Measurement, Energy Map

\section{Introduction}

Lately ecological clean energy sources are widely applied. Energy transportation, accumulation and transfer methods are being retrained. Combined utilization of several energy resources is appreciated as advantageous way. One of the clean one is wind energy. The energy is formed on the basis of temperature differences under the impact of the Sun[6]. wind energy is inexhaustible source, during year wind potential consists of $1,58 \cdot 10^{16} \mathrm{~kW} /$ hour $[1,4]$. In some references it is shown that wind energy is more than 80 trillion $\mathrm{kW} /$ hour in $500 \mathrm{~m}$ air layer. There is wind energy everywhere of the Earth. Unlike liqu id and firm other tradit ional energy sources, expenditure for energy generation and transportation don't appear while using wind energy. Speed an direction of wind possess stochastic character[2,11]. Whilst utilizing wind energy resource average annual wind speed, annual amount of windy hours and wind direction should be taken into account. Wind local speed mostly depends on the area relief (hills, mountain, rocky lands) and existing obstacles around (build ings, trees an so on)[12]. In order to protect, prevent the ecosystem from the anthropogenic impacts precautionary efforts' development can be based on the green energy application in all fields of our life and industry. It should be noticed that the investigation area (Pirgulu) have enough ecological clean energy (solar, wind and etc.) source.

At present energy deficiency and fall in the ecosystem development dynamics cause to the multiyear environ mental difficulties and risks for the nature. The questions in agenda are able to be solved by applying ecological clean, easy findable and generated renewable energy sources. Thus,

* Corresponding author:

uf samadova@yahoo.com (Ulviyya Mammadova)

Published online at http://journal.sapub.org/ajee

Copyright (C) 2012 Scientific \& Academic Publishing. All Rights Reserved today in majority of the world countries beside the most powerful solar energy, wind energy potential is also broadly used. For facilitating wind energy usage the current potential ought to be revealed. Therefore long-dated admeasurements have to be carried out and the obtained results are to be proceeded via mathematical statistical method $[8,11]$, then the final conclusion lets the wind energy map to be established. Because during wind energy plants production some technical parameters, installation facilities, exploitation possibility must be worked in advance. To proceed these necessary parameters wind energy potential is to be measured and total final wind energy has to be determined before manufacturing and projecting wind energy plants. According to the wind potential the type of the wind energy plant can be exacted. Thus selection of wind energy plant bases on the total wind energy potential of the area.

In Caucasus region Azerbaijan is the country having the greatest energy resources[5,10]. However the complete energy provision of the regions doesn't exist and the energy tariff price isn't fitting to the social economical state of the population. The present condition deepened the problem some more. Vast exploitation of forest resources[10,12] (especially wood) by energy, agriculture, build ing, furniture, paper and other industry fields influences on the ecosystem negatively. Provision of heat energy need by cheap and free energy sources leads to forest woods being hewed. Woodlands thinning, then gradual desertification of the woodless areas cause the soil degradation after the forests. Such soils undergo to the changing in morphogenetic structure, landslides in seismic region mainly at the result of earthquake risk[ 3,11$]$. Azerbaijan forests located mostly in geological seismic mountainous and foothill zones. It stands that some forests are being partly saved by the national parks, preserves, sanctuaries in the region, very little square of the total area concerning the forest foundation is safeguarded. That's why organization of all woodland territory protection in the Republic should be implemented by altering fuelwood by re- 
newable energy sources. Together other renewable energy potentials wind energy possibility is to be calculated and mapped for further procedure to begin. Wind energy application in the villages surrounding Pirgulu manage to supply heat energy necessity of the population $[1,8]$. This way may lag rapid hewing processes in the forests and reduce fuelwood demand.

Due to the claims of wind energy plants wind energy speed specifying taking into account the initial working speed is the inescapable factor. In the course of wind energy plant assemblage and exploitation in Pirgulu region these factors influence on the effectiveness. So the beginning wind speed is $3-5 \mathrm{~m} / \mathrm{sec}$ till $15 \mathrm{~m} / \mathrm{sec}$. the most sever winds speeds are certainly to be assigned whether there is in the territory. For organizing admeasurements in three main points the stationary stations have been defined and all the observations and mensurations were realized there. Forest is the obstacle for the wind formation. That's why it must be clarified that how and in what condition wind energy is able to utilized in the territory.

The woodland is undergoing to be cut is mostly situated in the west, southern-western, east parts of the preserve from 800 till 2000 (2200)m above sea level in broaden striae form $[7,12]$. Thus, within the woodlands there are woodless hills after long-sided huge cutting process. Also the village areas are without forests, extensive grasslands are suitable with the wind energy feasibilities. There is enough wind energy possibility beginning from $800(1500) \mathrm{m}$ height above the sea level where Sis river flows. In woodless squares including surrounding villages near Pirgulu such as; Avakhil, Kech meddin, Galaderesi, Sis Galeybugurd (in 1500-2500 m) in the vast grassland fields wind speed satisfies to be used $[2,9]$.

\section{Object and Methods of the Study}

Reducing population impact on the woodlands of these villages has to be supplied on the local, innate, ecological clean and economical profitable wind energy resource. In the course of long durational mensurating in the investigation area the height factor was taken into consideration. The three stations were selected in 800-2500 m height on the horizon. Accordingly to the study aim on the stations mensuration results were compared one another, the final conclusion was revealed. Wind speed is measured by both stationary and mobile anemo meter. After the first stage of the investigation average annual amount of non windy days on seasons, cold and warm periods of the year was estimated. The very indicates have been given below at the table.

As it is seen from the table 5 amount of windless days in April-September period is averagly 5 days, in OctoberMarch 6 days. During a year average amount of windless days is equal to 11 days. It shows that the rest days are windy, so in the zone there is proper potential to use wind energy. Besides the measurement of the necessary parameters, in order to measure the important wind energy potential, determination of the total amount of the windy day in the region is the first aim of the my work. Observations and dimension processes carried out in the selected area for the work the surrounding zone was taken into considration and at three points the measurents were realized, then the amount was defined. The results have been given at the following table.

From the table 6 it is known that the average annual wind energy potential with hours is 1712,3 hours/year. In the warm period (in April-September months) 1883 hours/year, in the cold period (in October-March) 1660 hours /year. Less average index is observed in winter and the $h$ igh inde $x$ is in summer months. The amount of the wind with hours depends on the height of the relief, characteristics of the air circulation, and other parameters of the region. That's why in the zone the amount of the seasonal, semi-annual, annual wind energy potential with hours is different. Averagely on seasons the greatest index is observed in summer months (780 hours), the least index is in winter months (143 hours). By the especial empric formula avreage annual wind speed $V_{H}^{\text {mou }}$ on the hieghts was appreciated.

$$
\overline{V_{H}^{\text {mou }}}=k_{f p}^{\text {mou }} \cdot \overline{V_{H}^{\text {plains }}}
$$

Table 1. The amount of the windless days at the Territory of Pirgulu State Nature Preserve

\begin{tabular}{|c|c|c|c|c|c|c|c|}
\hline \multirow{2}{*}{ Height (m) } & \multicolumn{7}{|c|}{ Territory of Pirgulu State Natural Preserve, (day) } \\
\cline { 2 - 8 } & spring & summer & autumn & winter & $($ Apr./Sept. $)$ & $($ Oct.Mar. $)$ & Annual \\
\hline $800-1000$ & 10 & 3 & 7 & 7 & 7 & 8 & 7,5 \\
\hline $1500-2000$ & 9 & 2 & 3 & 5 & 5 & 6 & 5,5 \\
\hline $2000-2500$ & 7 & 1 & 3 & 2 & 3 & 4 & 3,5 \\
\hline Average: & 8,6 & 2 & 4,3 & 4,6 & 5 & 6 & 5,5 \\
\hline
\end{tabular}

Table 2. The amount of the windy days with hours at the territory of Pirgulu State Nature Preserve (hours)

\begin{tabular}{|c|c|c|c|c|c|c|c|}
\hline \multirow{2}{*}{ Height (m) } & \multicolumn{7}{|c|}{ Territory of Pirgulu State Natural Preserve, (hour) } \\
\cline { 2 - 8 } & spring & summer & autumn & winter & $($ Apr./Sept. $)$ & $($ Oct.Mar. $)$ & Annual \\
\hline $800-1000$ & 550 & 730 & 550 & 360 & 1730 & 1540 & 1635 \\
\hline $1500-2000$ & 580 & 790 & 500 & 410 & 1850 & 1610 & 1730 \\
\hline $2000-2500$ & 600 & 820 & 650 & 470 & 2070 & 1830 & 1772 \\
\hline average: & 576 & 780 & 566 & 143 & 1883 & 1660 & 1712,3 \\
\hline
\end{tabular}


Table 3. Wind speed of the Territ ory of Pirgulu State NaturalPreserve $(\mathrm{m} / \mathrm{sec})$

\begin{tabular}{|c|c|c|c|c|c|c|c|}
\hline \multirow{2}{*}{ Height (m) } & \multicolumn{7}{|c|}{ Te rritory of Pirgulu State Natural Preserve, $(\mathrm{m} / \mathrm{sec})$} \\
\cline { 2 - 8 } & spring & summer & autumn & winter & $($ Apr./Sept. $)$ & $($ Oct.Mar. $)$ & Annual \\
\hline $800-1000$ & 2,5 & 3,6 & 2,4 & 2 & 3 & 2 & 2,5 \\
\hline $1500-2000$ & 2,7 & 3,8 & 2,6 & 2,3 & 3,8 & 2,6 & 3,2 \\
\hline $2000-2500$ & 3 & 4 & 2,9 & 2,8 & 4,2 & 3,7 & 3,95 \\
\hline average: & 2,7 & 3,8 & 2,6 & 2,4 & 3,6 & 2,8 & 3,22 \\
\hline
\end{tabular}

Table 4. Amount of the windy days having more than $15 \mathrm{~m} / \mathrm{sec}$ at the territory of Pirgulu State Nat ural Preserve (with days)

\begin{tabular}{|c|c|c|c|c|c|c|c|}
\hline \multirow{2}{*}{ Height $\mathbf{( m )}$} & \multicolumn{7}{|c|}{ Teritory of Pirgulu State Natural Preserve, (days) } \\
\cline { 2 - 8 } & spring & summer & autumn & winter & $($ Apr./Sept. $)$ & (Oct./Mar. $)$ & Annual \\
\hline $800-1000$ & 8 & 10 & 8 & 5 & 10 & 8 & 18 \\
\hline $1500-2000$ & 11 & 13 & 10 & 8 & 13 & 10 & 23 \\
\hline $2000-2500$ & 14 & 16 & 17 & 2,8 & 15 & 13 & 28 \\
\hline Average: & 11 & 16 & 11,6 & 5,3 & 12,6 & 10,3 & 23 \\
\hline
\end{tabular}

In the formula $k_{f p}^{m o u}$ - coefficient for estimaing average annual wind speed of mountainous and foothillous areas, $\overline{V_{H}^{\text {plains }}}$ - average annual wind speed in plains depending on height. Almost during the measurements in Pirgulu and surrounding area on horizon begining from $800 \mathrm{~m}$ to $2500 \mathrm{~m}$ height above the sea level the wind speed was measured and determined, then gave at the table.

From the table 7 it is known that in Pirgulu and the surrounding area average annual wind speed is $6,4 \mathrm{~m} / \mathrm{sec}$, for the warm period (April-September months) 3,6 m/sec, for the cold period (October-March months) this showing is 2,8 $\mathrm{m} / \mathrm{sec}$. As a rule, the higher average wind speed $(2,8 \mathrm{~m} / \mathrm{sec})$ is observed in summer, lower index $(2,4 \mathrm{~m} / \mathrm{sec})$ is in winter. The difference's not greater for two seasons, either.

Taking into consideration the temperature difference it should be noticed that windy generation probability is in summer. At the same time in Pirgulu and the surrounding area, a mount of the windy days having $15 \mathrm{~m} / \mathrm{sec}$ speed for a year was determined. On the stationary points seasonal and these days periodic a mount were given at the following table.

It is shown from the table 4.8. that the average annual amount of the windy days having more than $15 \mathrm{~m} / \mathrm{sec}$ speed equals to 23 days. Covering the warm period in April-March months amount of such days averagely is 12,6 , and covering the cold period in October-March months this showing is 10,3 days. The most sever ( $\geq 15 \mathrm{~m} / \mathrm{sec}$ ) winds (16 days) happen in summer season as a rule, the least one is observed in winter (5,3 days).

\section{Results and Discussions}

Depending on the height the differences appear in wind energy potential as solar energy potential. Generally gradient inde $x$ is taken into consideration in many natural phenomena while measuring and estimating the existing resources. Of course the gradient factor is generated by the distinction in relief form and height above the sea level.

Thus the investigation area is the mountainous zone, here per each $100 \mathrm{~m}$ height increasing is $1-1,2 \mathrm{~m} / \mathrm{sec}$. But the innate factor as the relief form, view direction, inclination, forest cover (forest density, forest kind and so on) of the slopes make the wind potential be distinguished on the heights. So the distinction for Pirgulu State Nature Preserve territory per each $100 \mathrm{~m}$, the wind gradient is $1,5 \mathrm{~m} / \mathrm{sec}$ is accepted. Generally gradient is the relief's production, because on the height distinctions gradient is calculated. Whilst calculating the wind gradient was taken into account and on the stationeries located in all three natural zone of the preserve the total energy potential was estimated. Accordingly due to the above given description wind energy potential distribution in Pirgulu along the year on the months differs. The distinction has been given at the graphic below.

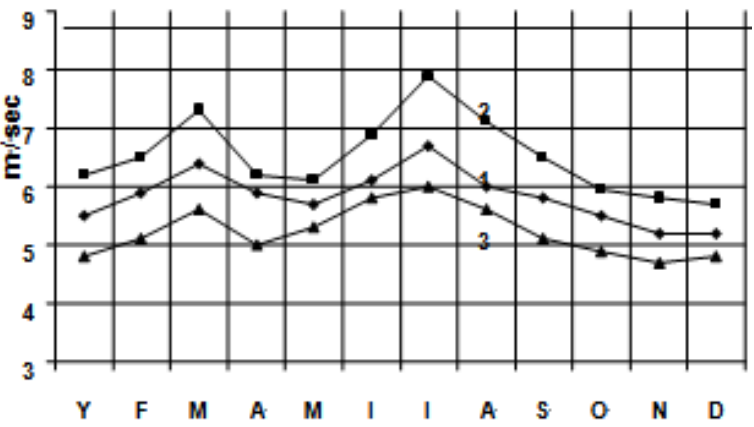

Figure 1. Dependence of wind speed $(\mathrm{m} / \mathrm{sec})$ on the months of the year in Pirgulu State Nature Preserve

Here 1 - medium wind speed, 2 - maximal wind speed, 3 minimal wind speed.

On the horizon in order to appreciate wind speed in autamatic mobile and stationary weather stations are so needed. As the investigation result of the admeasurements according to the total wind energy resource the wind potential map was developed

As seen form the map due to scale each $1 \mathrm{~mm}$ of the wind rose expresses $1 \%$ increasing in wind speed. The colors in the wind rose show the wind speed changing in the rage of $0-15 \mathrm{~m} / \mathrm{sec}$. almost weather stations amount located in the investigated area doesn't satisfy for estimation wind energy potential to be mensurated. 


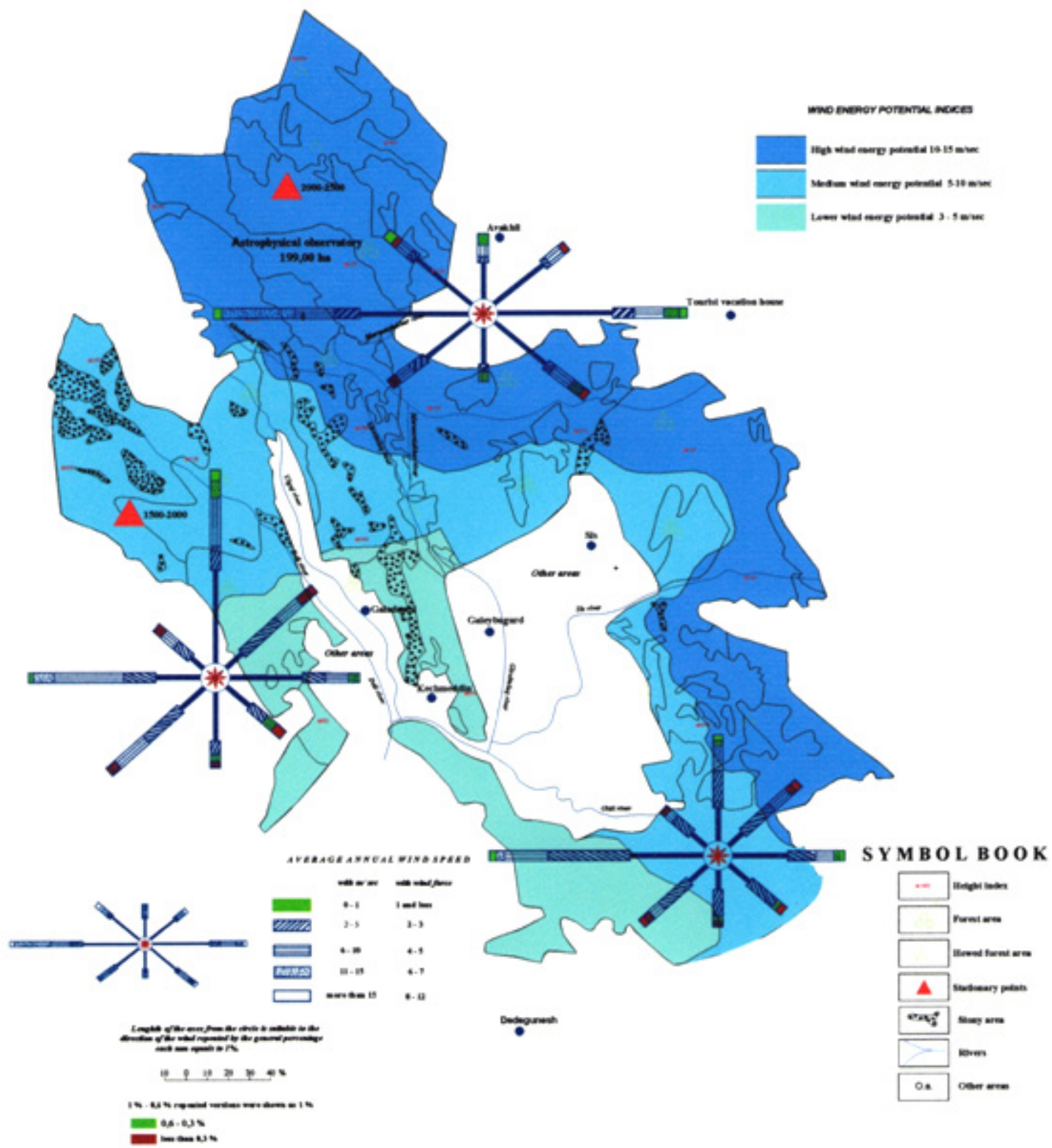

Figure 2. Annual total wind energy potential in Pirgulu State Nature Preserve of Azerbaijan on 1:25 000 scale

\section{Conclusions}

Though wind energy application is firstly proposed, that's ecological and economical validated offer and profitable for forest soils' protection. By using wind energy potential in the villages surrounding the woodlands instead of fuelwood, wealthy and soil protecting relict phytomass is able to be provided with safety. In order effectively to utilize wind energy potential, the practice of the leading world countries should be applied. Summering the investigation carried out in 800-2500 $\mathrm{m}$ above sea level in Pirgulu preserve territory some conclusions have been come into:

- Amount of average annual non windy days 5,5 days,

- Amount of average annual windy days 1712,2 hours, average index in April-September 1883 hours, in October-March 1660 hours;
- Amount of average annual wind speed $3,2 \mathrm{~m} / \mathrm{sec}$, in April-September 3,6 m/sec, in October-March 2,8 m/sec;

- Average annual index of windy days having $15 \mathrm{~m} / \mathrm{sec}$ speed 11,5 days, in April-September 12,6 days, in October-March 10,3 days have been estimated.

After having proceeded the data mensurated, finally wind energy application possibility has been revealed in the surrounging settlements next to Pirgulu for protecting forests.

Wind energy plants can be located and utilized for supplying electric ity demand of personal houses, schools, kinder gardens and other buildings.

Whilst determining and ecologically estimating both natural resources in mobile and stationary weather stations all mensuration processes were realized. Then it was revealed that there are 250-300 days sunny days and 250-279 windy days in Pirgulu region and surrounding villages. According to the statistical indexes innate potential gives op- 
portunity wind energy to be utilized in the region. In this case forest wood safety problem may be solved partly. The highest wind potential is useful in one hand but in another hand that's not profitable because of eol erosion of soils in woodless areas, cutting the woodlands on mountains leads to water and wind erosion of the soils then. In the preserve mostly on the northern directed slopes forest formation process delays a bit. Plant formation of such territories is nonres istant, thin therefore hewing process in the woodlands should be stopped. Go ing up under the influence of snow, ice water and high wind potential prevention of soils erosion in thinned forests and woodless areas is impossible.

Study of natural wind resources holds two purposes. The first is the energy need provision for the population living in the villages near Pirgulu. The second is the eol erosion risk rate estimation in soils on Pirgulu mountains.

\section{REFERENCES}

[1] Mammadov G.Sh., Samadova U.F., Mammadov F.F. Economical Estimation of Solar and Wind Energy Application as Alternative of Fire Wood. International Journal on Technical and Physical Problems of Power Engineering № 2, vol. 1. 2010, pp. 8-12.

[2] Mammadova U.F. Open Bonitation Scale of Forest and Woodless Soils in Pirgulu State Nature Preserve. Soilscience and Agrochemistry Journal XX vol, № 1. 2011, pp. 613-618.

[3] Mammadova U.F. Agroproduction Grouping of Forest and Woodless Soils in Pirgulu State Nature Preserve. Report of ANAS LXV vol, № 5. 2011, pp. 115-118.
[4] Mammadova U.F. Agro-Production Grouping of the Soils Under Forests and Woodless Areas of Shamakhi in Azerbaijan. Resources and Environment Journal № 2, vol. 1. 2012,pp. $7-11$.

[5] Mammadova U.F. Ecological Estimation of Forest soils in Azerbaijan. Journal of Ecology and The Natural Environment № 6, vol. 3. 2011, pp. 181-185.

[6] Mammadova U.F. Soil Study of Woodland in Pirgulu State Nature Preserve of Azerbaijan. World Environment Journal № 2, vol. 1. 2012, pp. 41-45.

[7] Mammadova U.F. Study and Main Bonitation Scale of Forest and Woodless Soils in Pirgulu State Nature Preserve. Ecology and Water Industry Journal № 4. 2011, pp. 22-25.

[8] Mammadova U.F. Study of Azerbaijan Forests' Ecological State. Conference Material on Improvement of Agrarian Science by Solving Food Safety Provision Problems. Guba: 2011, 14-16 May, pp. 381-389.

[9] Mammadova U.F. Study of Woodless Soils in Pirgulu State Nature Preserve. Report of ANAS LXV vol, № 1. 2012, pp. 115-118.

[10] Samadova U.F. Importance of Solar and Wind Energy Application for Ecology Situation Protection. Science Without Borders № 6, vol. 3. 2007-2008, pp. 256-258.

[11] Samadova U.F. Municipality and Ecology: the current problems their possible solution ways. Importance of Solar Energy to the Environment. Baki: 2006, pp 132-135.

[12] Samadova U.F. Solar and Wind Energy Application for the Woods and Forest Soil's Protection. Renewable Energy Congress X, Glasgow, Scotland 2008, 19-25 July, pp 512-514. 